\title{
Topic, Focus and null subjects in Old French
}

\author{
RICHARD INGHAM \\ University of Westminster \\ r.ingham@westminster.ac.uk
}

\begin{abstract}
Old French subject pronouns (Spro) were omissible if postverbal (Foulet 1928), but not freely so (Vance 1997, Zimmermann 2014). This article addresses their partial omissibility in discourse-syntax terms, following work on partial null subject languages by Holmberg and Nikanne (2002) and Modesto (2008). An observational study of dialogic responses in 13th century prose romances is first reported, finding strong indications of covariation between the Topic/Focus status of an initial non-subject constituent and the expression/omission of post-verbal Spro. A quantitative investigation, in such texts, of preposed discourse-linked anaphoric constituents and preposed intensifiers, taken as diagnostic of Topichood and Focushood respectively, confirmed this analysis. We take null Spro to be available (i) when a null Topic operator targets left-peripheral TopicP, and (ii) with a left-peripheral Focused expression. When a discourse-linked non-subject constituent occupies TopicP, however, Spro must be overt.
\end{abstract}

Keywords: Null subjects, left periphery, Old French, Focus, Topic

\section{Résumé}

En ancien français, on pouvait effacer un sujet pronominal en position postverbale (Foulet 1928), sous certaines conditions (Vance 1997, Zimmermann 2014). M'inspirant des recherches de Homberg et Nikanne (2002) et de Modesto (2008) sur les langues partiellement pro-drop, je propose que cet effacement conditionnel s'analyse en termes de syntaxe discursive. L'article présente d'abord une étude de couplets question-réponse recueillis dans des romans en prose $\mathrm{du} 13^{\mathrm{e}}$ siècle où on peut observer un rapport étroit entre l'effacement d'un sujet pronominal et le statut discursif - soit topique, soit focus - du syntagme phrastique initial. Une analyse quantitative de ces syntagmes en initiale de phrase qui contiennent d'une part une expression anaphorique et d'autre part un intensificateur vient appuyer cette hypothèse et permet de conclure qu'un Spro non exprimé est légitimé en ancien français en présence, soit (i) d'un opérateur nul Topique ciblant un TopP situé dans la périphérie de gauche, soit (ii) d'une expression focalisée. Par ailleurs, lorsqu'un syntagme discursivement lié (autre que le sujet) occupe la position TopP, un sujet pronominal ne peut être effacé.

Mots-clés: Sujets nuls, périphérie gauche, ancien français, Focus, Topique 


\section{INTRODUCTION}

A long-standing problem in Old French syntax is to account for the variability in subject pronoun realisation (see, e.g., Foulet 1935/6, Price 1973, Roberts 1993, Vance 1997, Rinke 2003, Ingham 2005, Prévost 2011, Zimmermann 2014). ${ }^{1}$ As can be seen from the representative set of example data in (1 a-d) below, taken from early 13th century narrative prose, an overt Subject pronoun (henceforth Spro) could appear either before the tensed verb, or after it if a nonsubject constituent stood in first position, whereas a null subject occurred only in the latter eventuality.

(1) a. Ele vint as deus rois.

She come-PRET to-DEF.PL two king-PL

'She came to the two kings'

(La mort le roi Artu, p. 169)

b. Et por ce vos vint ele veoir.

And for this you-OBJ come-PRET she see-INF

'And therefore she came to see you'

(La queste del saint Graal, p. 185)

c. Lors vint a son cheval.

Then come-PRET to his horse

'Then s/he came to his/her horse'

(La queste del saint Graal, p. 145)

d. *Vint a son cheval.

come-PRET to his horse

(unattested) $^{2}$

For Foulet (1935/6), optional expression of Spro was possible only when Spro, if expressed, would have followed the verb, an analysis generally maintained in subsequent studies. What may have influenced the choice between XVSpro and XVØ has received relatively little attention, however, and forms the issue explored in this article. An exception was Price (1973) who noted that after certain clause-initial adverbs such as molt 'much, very' Old French subject pronouns were rare to nonexistent, whereas after others such as or 'now' they were far more common. This suggested a line of enquiry which turns out to be a fruitful one to pursue, as may be seen.

Within contemporary syntactic theory the question has tended to be whether Old French was a null-subject language typologically. Roberts (1993) and Rinke (2003) considered that it was, whereas Zimmermann (2014) argued to the contrary. However, the question should not be seen as a binary choice, since research has demonstrated the existence of partial null-subject languages such as Finnish and Brazilian Portuguese (Holmberg and Nikanne 2002, Modesto 2008), in which

\footnotetext{
${ }^{1}$ The following abbreviations are used: A-topic: Aboutness-shift Topic; COND: conditional; DEF: definite; EPP: Extended Projection Principle; FEM: feminine; FUT: future; IMP: imperative; IMPF: imperfect; INF: infinitive; NEG: negative; OBJ: object; PAST: past; PL: plural; PPART: past participle; PRES: present; PRET: preterite; REFL: reflexive; S: subject; sG: singular; Spro: subject pronoun; suBJ: subjunctive; V2: verb second.

${ }^{2}$ This root clause construction is unattested in the 13 th $\mathrm{c}$. Old French prose works examined in the present study. Known as V1, it was possible in 12th c. verse, where the verb appears to have been fronted for discourse purposes (see, e.g., Labelle and Hirschbühler 2005). It seems to have been stylistically marked, and possibly a relic of an archaic construction, by the time of the data analysed here.
} 
subjects may be left null in restricted contexts. ${ }^{3}$ The observation is that these languages allow definite 3rd person null subjects only when they are coreferential with the subject of a higher clause. This constraint does not apply in consistently null-subject languages. The partial availability of null Spro in Old French suggests it may be amenable to a similar type of analysis.

The null subject parameter has in recent years been remodelled in Minimalist Program terms by expressing the alternative parameter values as whether or not a finite $\mathrm{T}$ hosts a [D] feature, intended to represent definiteness. In a full null-subject language such as Italian, the $\mathrm{T}$ head will indeed host this D-feature, whereas this will not be the case in non-null-subject languages. Holmberg (2010) refines this approach by postulating that the D-feature is valued either by an overt subject or by a null topic in $[$ Spec, $\mathrm{CP}]$ which provides a referential index for a null subject. Here Holmberg adopted Frascarelli's (2007) notion of an Aboutness-shift Topic (A-topic), which in turn goes back at least to Grimshaw and Samek-Lodovici (1998), who required null subjects to be licensed by an antecedent with the discourse status of topic. According to Frascarelli, an A-topic is syntactically represented in CP, either overtly or covertly. We propose here that an analysis along these lines can be applied to Old French in such a way as to explain what influences the (non-)expression of Spro. The null Aboutness Topic will be taken as an operator over a variable in the clausal Subject position, following Modesto's (2008) analysis of partial null subjects in Brazilian Portuguese.

The structure of the paper is as follows. First, previous accounts of subject pronoun optionality are discussed, followed by an examination of data that shed light on some of the issues raised by previous analyses. An observational survey of how null and overt Spro patterned in dialogic responses in Old French narrative prose is reported, then a quantitative analysis of Old French V2 clauses is conducted, comparing the syntax of clauses featuring intensifying elements and anaphoric expressions in first position. The narrative prose sources used feature a large amount of dialogue in which nonsubject constituents are shown to be fronted for clearly identifiable discourse reasons. These are taken to be clear cases of focusing and topicalisation, respectively, of the first-position constituent. Thereafter an analysis of null subjects as variables bound by a null Topic is proposed as a way of accounting for the data patterns observed. Our analysis is limited to Old French (up to circa 1300), and no claim is made regarding subsequent developments in the language, as the V2 constraint began to be relaxed after the 13th century. The enquiry is restricted to the domain of root clauses, as these constitute the paradigm case of the null subject phenomenon in the Old French period.

\footnotetext{
${ }^{3}$ Zimmermann (2014) points to the existence in even canonical obligatory-subject languages of apparent null-subject constructions, but these are lexically, not structurally, conditioned, unlike in the cases studied in the research cited here.
} 


\section{Null SUbJeCtS in OLd French}

The status of null Spro in Old French is generally linked to the validity of the V2 analysis of root clauses accepted by many - though by no means all - researchers (cf. Kaiser 2002, Elsig and Rinke 2007). Following Labelle and Hirschbühler (2005: 61), we assume that the main clause left periphery normally had the configuration outlined in (2).

(2) $[\mathrm{ZP}[\mathrm{FinP}[\mathrm{TP} \quad \ldots]]]$

FinP was the position to which the finite verb moved, while ZP represented a discourse-sensitive projection which they considered to host Topic and Focus constituents (see below, however, for a somewhat different approach to Focus). The generally verb-second character of Old French can be handled by assuming that only one constituent moving to the left periphery could traverse [Spec,FinP]. A clause with postverbal Spro, such as (1b), can then be given the analysis in (3), to be further refined below.

(3) (Et) [zP por ce [FinP vos vint [TP ele ] ] ]

In a true null-subject language such as Italian, where a subject pronoun is normally left unexpressed, its overt use signals some special discourse effect. Certain authors, especially Vance (1997) and Zimmermann (2014), have also sought to investigate whether in Old French the expression or omission of Spro is discourse-driven. Vance (1997), focussing on the syntax of the prose romance La Queste del saint Graal, saw the choice between $\mathrm{XV}^{4}$ and XVSpro as depending on the relation between the initial constituent $X$ and the discourse context in which the clause appears. Basing her analysis on Jakobsen's markedness theory, in which the unmarked member of a formal opposition is neutral with respect to the feature in question, she took $\mathrm{XV} \varnothing$ as unmarked, with no particular discourse conditioning, but XVS, the marked member, to be discoursally conditioned. She found that it virtually always showed the property [+ deictic linking to the discourse], while XV could, but often did not, show this property. Her findings thus appeared to corroborate only a one-way prediction: that XVØ occurred when the initial X constituent was deictically linked to the discourse. Being unmarked, XVØ was also found when $\mathrm{X}$ was new information, as in (4).

(4) a. Perceval, traie m' avez.

Perceval, betray-PPART me have-2PL

'Perceval, you have betrayed me'

(La queste del saint Graal, p. 110)

b. Sire, nouveles vos apport molt merveillleuses.

Sire, news you bring-1PL-PRES very wonderful

'My Lord, I bring really astonishing news' (La queste del saint Graal, p. 5)

A complication that Vance herself recognised, however, was that the situation as regards the discourse linking factor associated with XVSpro order appeared to

\footnotetext{
${ }^{4}$ We have replaced Vance's label 'C(omplement)' for the clause-initial constituent by the more neutral term ' $\mathrm{X}$ '.
} 
change over time. In 12th $\mathrm{c}$. verse it was very common for a discourse-linked $\mathrm{X}$ to appear with a null subject, whereas by the 13th c. this was less usual..$^{5}$ In addition, dialogue showed far more use of overt Spro than narrative, a fact she related to the assumption that innovative tendencies are more visible in speech than in writing. ${ }^{6}$

Vance (1997) did consider conditions on the omissibility of Spro, pointing to a strong tendency for Spro to be expressed if a clause-initial element was deictic or anaphoric. However, her analysis was limited to a small number of adverbs such as or 'now', which seemed to require a pronominal subject to be overt when deictic, but to allow optionality when an argumentational introducer, with the same function as the English 'now' has, in the sentence 'Now this is a very significant point'. As with Price (1973), Vance made lexically specific observations without embedding them in a more general analysis of subject pronoun use or omission.

The realisation or omission of a subject pronoun was also investigated in relation to lexically specific items by Marchello-Nizia (1985), who studied the very common Old French sentential particle si. In our examples below, the subject pronoun $i l$ is used when si relates the clause it introduces to the content of the preceding clause, similarly to its Latin etymon sic:

(5) Certes endroit de moi voudroie surely place of me wish-COND.1sg I that it you of-it fail-suBJ.PAST.3sG et ge cuit que si fera il. and I think-1sG that SI make-Fut.3sg it 'Certainly for my part I wish you will fail, and so I believe you will.'

(La mort le roi Artu, p. 192)

In (6), however, si appears to have a different function, of reversing the polarity of the previous clause, and this time the subject pronoun is omitted.
(6) - Ele ne trouvera ja si bon chevalier qui por lui deffendre She NEG find-Fut.3sg ever so great knight who for her defend en ost prendre son escu. in army take-INF his shield

- Certes, fet Lancelos, ge cuit quesi fera; Surely, make-PREs.3sg Lancelot I think.PREs.1sG that SI make.FUT.3sg 'She will never find so good a knight who will take his shield in battle to defend her. Assuredly, said Lancelot, I believe that she will.' (La mort le roi Artu, p. 94-95)

When $s i$ has the sense of 'nevertheless', thus activating the previously expressed proposition with which it contrasts the content of its own clause, we again find that the subject pronoun is expressed, as in (7).

\footnotetext{
${ }^{5}$ Whether this was an artefact of analysing verse for the 12th and prose for the 13th centuries was not discussed by Vance, but is clearly a possibility in view of the period/text type confound in the data sets used. Unfortunately, the unavailability of freely composed Old French prose narrative before the 13th c. makes this a difficult question to resolve.

${ }^{6}$ The present author's comparison of speech-based and written-genre sources in AngloNorman (Ingham 2016) obtained the same finding.
} 
(7) Jamés n' ere a aise devant que je sache certainement que ever NEG be-FUT.1sg at ease before that I know-SUBJ.1sg certainly what il senefient et si en sai je une grant partie. they mean and SI of-it know-PRES.1sG I a great part 'I shall never be at ease before I know for sure what they mean, even though I know a lot about them.'

(Lancelot du Lac: La fausse Guenièvre. Tome III, p. 68)

Marchello-Nizia calls this the 'si adversatif' use of the particle. However, when the clause introduced by the particle simply moves the discourse forward by introducing new information, as in the last clause in (8), the subject pronoun is not expressed.

(8) Il ne porra croire en nule maniere que Mordrés ne $\begin{array}{llllll}\text { He NEG be-able-FUT.3SG believe-INF in any manner that } M . & \text { NEG } \\ \text { m' ait } & \text { conneüe charnelment, por la grant force qu'il } \\ \text { me } & \text { have-SUBJ.3sG } & \text { know-PPART } & \text { bodily } & \text { for the great force that he }\end{array}$ a mise en moi avoir; have-PRES.3sG put-PPART in me have-INF si sei veraiement qu' il m' ocirra. SI know-PREs.1sg truly that he me kill-FUT.3sG 'He won't be able to believe in any way that Mordred took my body thanks to the force he used to possess me, and I know he will kill me.' (La mort le roi Artu, p. 217)

Vance (1997) notes that in the prose romance she used as a source, 1st and 2nd person pronouns, which are used in dialogue, were more often overt, whereas 3rd person subjects, most commonly used in narrative, were more often null. This observation was reinforced by Prévost's (2011: 174) corpus study of Old French subject pronoun use, in which she observed a higher frequency of omission of 3 rd than of 1 st person pronouns. Although she did not draw this conclusion, it could be argued that 3rd person referents tend to maintain the existing discourse topic to a greater extent than 1st person referents, so the finding of Prévost (2011) appears to be discoursally based rather than relating to a grammatical property of Old French.

Research studies such as these have provided accounts of specific contexts in which subject pronoun omission /realisation could be associated with discourse properties, but a general overview of the question has up to now been lacking. A more recent study of mediaeval French subject pronoun use - Zimmerman (2014) - did, however, consider the issue in broader terms, relating subject pronoun use in V2 contexts to the nature of the clause-initial constituent. For Zimmerman, Old French was not a null subject language as such, but one in which subject pronouns were generally obligatory, save in certain specific contexts (a point which he noted also applies to the modern language). As with earlier generative authors, he posited that a null subject is licensed in a configuration where the finite verb of the clause has raised to $\mathrm{C}$, so that it can govern the position of the null subject $(S \varnothing)$, for instance:

(9) $\left[\begin{array}{llllll}\mathrm{CP} & \mathrm{XP} & \mathrm{V}^{\mathrm{fin}} & {[\mathrm{TP}} & \mathrm{S} \emptyset & \ldots\end{array}\right]$

Zimmermann's account of when Spro was overt or null posited that subjects were null after a pre-verbal XP 'which receives special emphasis' and is naturally 
interpreted as focused information. For Zimmerman (2014: 140) "in declaratives with non-expressed subject pronouns and a verb preceded by a single constituent, this constituent is focalised." This is the view taken in the present study. However, he went on to formulate the matter in terms we find much less convincing, given in (10).

(10) The pre-verbal constituent in V2 configurations in declaratives in Old and Middle French invariably represents a focus element.

(Zimmermann 2014: 140)

Apparently referring to all V2 clauses, not only those with null subjects, he thus rejected earlier analyses of the preverbal constituent in Old French V2 clauses as a topic. Zimmermann (2014: 150-151) furthermore argued that the presence of a topic is not correlated with $\mathrm{V}$-to-C, but that the presence of a focused element is. Referring to our example (11) below (his ex. 32b), he considered the pre-verbal constituent in $\mathrm{V}$-to-C contexts as a focus: "The directly preverbal constituent in [this example among others cited] constitutes a focus element" (Zimmermann 2014: 153).

(11) Et pour ce vaut il miex, si comme il me semble, and for this be-worth-PRES.3sG it better so as it me seem.PRES3.SG que nous le façons occirre avant qu' il nous parte des mains.

that we him make-SUBJ.1PL kill-INF before that he us leave-SUBJ3sG of-the hands

'And because of this, then, it would be better, so it seems to me, that we have him killed, before he slips from our hands'

(Saint Louis, p. 172)

Appreciating that this stands at variance with his previously stated position, he dismissed such cases as 'marginal', however, and maintained his claim that 'the presence of a (left peripheral) focus element is principally restricted to declaratives with non-expressed subject pronouns" (Zimmermann 2014: 154).

It seems to us, on the contrary, that this case is not at all marginal, but rather represents the ordinary situation in Old French when a preposed constituent is deictic, as indeed Vance's (1997) investigation of or would lead us to suggest. What seems required to resolve this issue, therefore, is a detailed study, taking discourse context into account, of the varying discursive properties of clause-initial constituents and how they related to pronominal subject realisation. The investigation reported here attempts to make up for this apparent gap in our knowledge.

\section{INTRODUCTION TO THE STUDY}

Researching the relationship between syntax and discourse is far from straightforward in contemporary languages, and when studying historical language states the challenges become much greater. The main problem is, of course, the loss of prosodic information when only written text is available, as prosody very often provides clues to the foregrounding and backgrounding of information (Lambrecht 1994, Zubizarreta 1998), as well as to the attitudinal stance taken by the speaker to the propositional content of the discourse. However, the contextual information provided by 
surviving texts themselves may well furnish sufficient material to determine very plausibly the status of a constituent as denoting focused or topicalised information. This is particularly the case in fictional narrative texts where characters exchange information, especially in dialogic form. Through dialogic exchange, their knowledge 'slate' is continually presented as being updated, and the linguistic structuring of that information can be studied so as to relate possible regularities in the positioning of constituents on the one hand with the information status of the content of these constituents on the other. This approach is pursued in the present study.

The crucial concepts in this analysis of information structure are first, Topic who or what the proposition is presented as being about, understood as given by the discourse context -, and secondly Focus. This can be taken in Lambrecht's (1994) narrow-focus sense, where a non-predicate constituent is focused, as in (12).

(12) Q: I heard your motorcycle broke down. A: My CAR broke down.

(Lambrecht 1994: 223)

This English example signals Focus by prosodic highlighting (represented orthographically by capital letters), but we will be interested in the extent to which word order modification, specifically movement to the left periphery, may have achieved the same result in Old French, as studied by Labelle and Hirschbühler (this volume), who note that the left periphery hosted focused as well as topicalised expressions. In addition, word-order modification may support emphasis (Zubizarreta 1998), and it will be seen below that emphatic focus is a notable characteristic of the Old French left periphery. Corrective uses of argument focus, as in (12), were found to be rare, and are not therefore considered as the central type of Focus to be addressed here.

\subsection{The Left Periphery in dialogic text: a preliminary investigation}

We approached the issues to be explored in this study by first making an observational examination of dialogic discourse in early 13th c. narrative prose. Numerous texts of this type exist in published sources, though not many of them have been digitised in electronic corpora. As the aim was to gain an impression of the effect of discourse context, close reading of the texts and extraction of data by hand, albeit rather time-consuming, seemed to be of value, which compensated for the ease of data collection normally associated with electronic corpus use. The main point of interest lay in what, in discourse terms, are known as adjacency pairs (Schegloff and Sacks 1973), especially concerning the syntactic form of the second speaker's response to the first speaker's utterance. Such contexts allow the syntax of Information Focus to be observed in responses to Wh-questions: the constituent supplying the requested information is clearly new and the most communicatively salient part of the message.

In the texts studied, Information Focus was normally positioned postverbally, as in (13). 
(13) a. O volez vous aler? Dame, fait il, je voil Where want-PRES.2PL you go-INF lady make-PRES.3SG he I want-PRES.1sG aler jusqu' en ce bois. go-INF as-far in that wood

'Where do you want to go? Lady, he said, I want to go that wood.'

(Lancelot du Lac. Tome I, p. 396)

b. Sire, fet

Sir make-PRES.3sG il? Qui estes vos? Je sui, fet il, Gauvains li niés lo roi Artur. I be-PRES.1sG make-PRES.3sg he Gawain the nephew the king Arthur 'Sir, he said, who are you? I am, he said, G. the nephew of King A.'

(La queste del saint Graal, p. 155)

However, it could sometimes be found in preverbal position, as in (14).

$$
\begin{aligned}
& \text { (14) - Sire, fait Gualehoz, qui estes vos? } \\
& \text { Sir, make-PREs.3sg G. who be-PREs.2PL you }
\end{aligned}
$$

- Biaus sire, uns chevaliers sui.

fair sir a knight be-PRES.1SG

'Sir, said G., who are you? Fair Sir, I am a knight.' (Lancelot du Lac. Tome I, p. 832)

Likewise, new information elicited by imperatives could also appear preverbally, as in (15).

$\begin{array}{rllllll}\text { (15) a. - } & \text { Mes or } & \text { me dites ou nos vos porrons } & \text { trover } \\ \text { But now } & \text { me tell-IMP where } & \text { we } & \text { you be.able-Fut.1PL find-INF } \\ \text { Quant nos } & \text { vendrons ceste } & \text { part. } & & \\ \text { When we } & \text { come-FUT.1PL this part } & & \end{array}$

'But now tell me where we'll be able to find you when we come that way'

- En ceste place meismes, fet il, me troverez.

In this place same make-PREs.3sG he me find-Fut.2PL

'In this place here, he said, you will find me.' (La queste del saint Graal, p. 30)
b.- Or me dites, fait il, lo non au chevalier. Now me tell-IMP make-PREs.3sG he the name to-the knight

- Desouz cele lame, fait ele, de metal lo troveroiz. below this blade make-PREs.3SG she of metal it find-Fut.2PL 'Now tell me, he said, the knight's name. - You'll find it underneath this strip of metal'

(Lancelot du Lac. Tome I, p. 554)

The significant point in these cases is that when information focus is preverbal, the clause subject was left null. By contrast, when the second speaker in an exchange pair repeated an expression used by the first speaker, a pronominal subject was used, as in (16).

$$
\begin{aligned}
& \text { (16) a. - Biau sire, vendrez vos a la cort lo roi Artur auvec moi? } \\
& \text { Fair sir, come-Fut.2PL you to the court the king A. with me } \\
& \text { - Auvec vos n' irai je pas. } \\
& \text { with you NEG go-Fut.1sG I at-all }
\end{aligned}
$$


'- Sir, will you go to King A.'s court with me? - I won't go with you.'

(La queste del saint Graal, p.3)

b. - Si vos pri por Deu que vos me pardonez lo meffait. SI you ask-PRES.1SG for God that you me pardon-PRES.2PL the misdeed

- Certes, fait il, meffait n' i voi ge nul. Surely make-PRES3.SG he misdeeed NEG there see-PREs.1sG I any) '- I beg you before God to forgive me this misdeed. - Assuredly, he said, I can see no misdeed.'

(Lancelot du Lac. Tome I, p. 492)

No cases were found in the response member of the exchange pair where repeated information in first position was accompanied by a null subject.

Preverbal Information Focus seemed rather infrequent, however, so the issue was approached from the other direction, asking what kind of preverbal constituent favoured a null subject. Dialogic texts were manually examined for cases where no subject was expressed, following any type of preposed constituent. ${ }^{7}$ Three prose romances from the first half of the 13th century were used for this purpose. ${ }^{8}$ Contexts were analysed where a V2 main clause with a nonsubject constituent in first position was the second member of any dialogic exchange, not only in question-answer pairs. ${ }^{9}$ Cases of null subjects in these clauses were identified, and the nature of the initial constituent in discourse terms was noted. Twenty-nine examples were obtained, all of which seemed interpretable in terms of some type of focusing, as in (17).

(17) a. Sire, fet Boorz, por noiant i demorroie.

Sire, make-PREs.3sG B. for nothing there stay-COND.1sG

'Sire, said Boris, I would not stay here for anything.' (La mort le roi Artu, p. 82)

b. Par mon congié ne movrez hui mes.

By my authority NEG move-FUT.2PL today more

'You will go no further today on my authority.' (La queste del saint Graal, p. 242)

The initial constituent appeared in some cases to be evaluative, as in (18).

(18) a. Car mauvesement vos estes contenue envers moi.

For badly you be-PREs.2PL behave-PPART towards me

'For you have behaved badly towards me.' (La mort le roi Artu, p. 112)

b. Feme, merveilles as fet.

woman wonders have-PRES.2SG do-PPART

'Woman, you have done wonders.' $\quad$ (La queste del saint Graal, p. 542)

\footnotetext{
${ }^{7}$ Instances of preposed ja and onques were omitted, as they were already known to have a special syntactic status: Foulet (1928) called these adverbs 'non invertissants', yet they regularly co-occur with null subjects, in both main and subordinate clauses (Ingham 2005). On the basis of their unusual behaviour, they were set aside from the present investigation.

${ }^{8}$ These were La Mort le roi Artu, La Queste del saint Graal, and Roman de Tristan en prose.

${ }^{9}$ Initial adverbial clauses were not considered for this purpose, as in the 13th century they were already undergoing change towards a non-V2 grammar lacking postposition of subjects (Donaldson 2012).
} 
In such cases, the initial elements served to intensify the speaker's commitment to the proposition expressed, rather than relate it to the discourse context. They thus seem to be conveying Emphatic Focus, rather than merely the preposing of new information as in (14)-(15). This was particularly clear when the initial constituent was an adverb of intensity (Buridant 2000: 742), supporting Price's (1973) observation that adverbs such as molt 'much' strongly disfavoured overt subject pronouns when preposed, as in (19).

(19) a. Moult m' avez bien paiee de ceste parole. Much me have-PRES.2PL well reward-PPART of that word 'You have well rewarded me for saying so.'

(La mort le roi Artu, p. 10)

b. Messire Gauvains [...] dist

a Boort: Trop me merveill

Sire G. Say-PREt.3sg to B. Much me wonder-PREs.1sG que messires Lancelos n' a esté a ceste assemblee that Sir Lancelot NEG have-PRES.3SG be-PPART at this meeting. 'Sir Gawain said to Bohort: I'm very surprised that Sir Lancelot wasn't at this meeting.'

(La mort le roi Artu, p. 88)

In current syntactic terms, they therefore involved the $\mathrm{CP}$ projection, rather than some extraposed position not affecting the syntax of the clause. The interpretation of the adverb moult as modifying a clause-internal element such as paiee in (17b) or dolente in (18), indicates that the adverb has raised out of its base position into CP.

Note that when the clause subject was a nominal, it was always inverted following a preposed adverb, as in (20).

(20) Moult est la reïne dolente de ces noveles. Much be-PREs.3sg the queen sorrowful of these news 'The Queen is very sorrowful at this news.' (La mort le roi Artu, p. 32)

That is, the syntax of preposed focus constituents obeyed Foulet's generalisation in relation to (1), at least in that inversion took place with a nominal expression, meaning that preposed intensifying adverbs did not belong to his 'non-inverting' category of adverbs such as certes.

The next step was to ascertain what kind of initial expression in these dialogic responses typically favoured overt subject pronouns. In accordance with Vance (1997), overt subject pronouns were most commonly found after an anaphoric initial constituent, especially one involving a demonstrative expression such as ce 'this/that', as in (21).

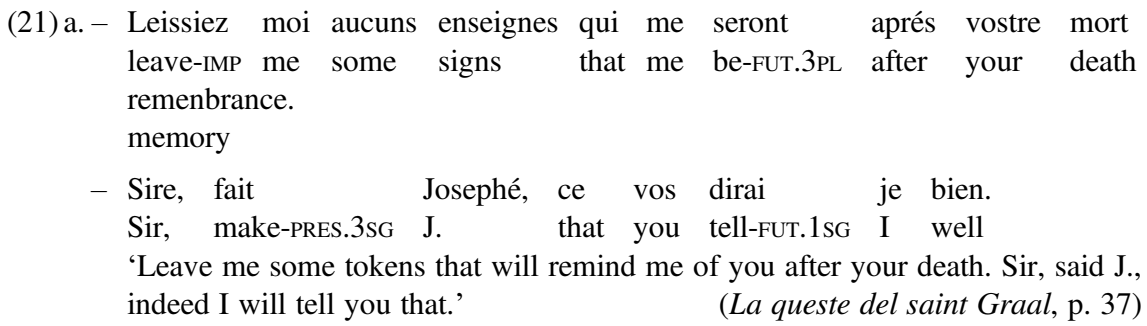




$$
\begin{aligned}
& \text { b. - Volez vos que ge aille avoc vos? } \\
& \text { want-PRES.2PL you that I go-SUBJ.PRES.1SG with you } \\
& \text { - De ce sui ge mout liez, fait il. } \\
& \text { Of that be-PREs1sG I much happy make-3sg he } \\
& \text { 'Would you like me to go with you? - I'd be very happy about that, he said.' }
\end{aligned}
$$

(Lancelot du Lac. Tome I, p. 628)

In such cases, null subjects seemed to be avoided. The adverb donc (sometimes spelled dont), in the sense of 'consequently', likewise avoided null subjects, as in (22).

$\begin{array}{llll}\text { (22) a. - } & \text { Sire, me fetes } & \text { vos droit de doner a la reïne si lonc respit? } \\ \text { Sire, me make-PRES.2PL } & \text { you right of give-INF } & \text { to the queen such long wait }\end{array}$

- Oill, fet li rois, ce sachiez vos veraiement. Yes make-PREs.3sg the king that know-SUBJ.2PL you truly.

- Dont m' en irai ge, fet il.

So me of-it go-fut.1SG I make-PREs.3sg he

'Sire, will you allow me to give the queen such a long wait? Yes, said the king, you can be sure of that. - Then I will go, he said.' (La mort le roi Artu, p.87)

b. - Je vos conois, fet li preudons, mout mielz I you know-PRES.1sG make-PREs.3sg the good-man much better que vos ne cuidiez. -Biau sire, fet Gauvains, donc than you EXPL think-PRES.2PL fair sir make-PRES.3SG Gawain then me vos bien dire, s' il vos plest, en quoi... me be-able-PRES.2PL you well say-INF if it you please-PREs.3SG in what 'I know you, the good man said, much better than you think. Good sir, said G. then can you please tell me in what...'

(La queste del saint Graal, p. 52)

As an overall impression of the data from this observational study, it can be said that an overt pronominal subject was disfavoured if new and apparently focused information was positioned preverbally. Overt subject pronouns, however, were favoured by old information, as well as by material linking the clause to the preceding discourse anaphorically, through the use of either a demonstrative expression or an adverb expressing a logical relationship, such as donc. In quantitative terms, the results of this exploratory study are not on a scale allowing a conclusive statement to be made on the discourse syntax of Old French. However, they are in line with earlier observations by Marchello-Nizia (1985) and by Vance (1997) in that the distribution of null subjects seems not to have been random, but co-varies with properties of items in the left periphery. Provisionally, they also suggest that the association made by Zimmerman (2014) between null subjects and focusing is correct, though only in the sense of Focus we adopt here, associated with new information and thus excluding deictic/anaphoric expressions (see example (11) above). Vance (1997) already made a convincing case for an association between overt Spro and a preposed deictic constituent, so we can then ask if subject omission and realisation can be distinguished on the basis of whether the discourse role of an initial nonsubject constituent is Focus on the one hand, or Topic, on the other. In the main study reported in section 3.2, frequency data are brought to bear on this question. 


\subsection{Preverbal anaphoric expressions and intensifiers: a quantitative study}

In the previous section, indications were found that two types of initial constituent behaved very differently as regards null subjects: the first where constituents contained an anaphoric expression that could be considered a sentence Topic, and the second involving constituents with what appeared to be a Focus interpretation. The initial survey was not conducted on a quantitative basis, however, and it was held desirable to gain a more authoritative view of the distribution of null and overt pronominal subjects in these contexts. For this purpose, electronic corpus data were sought, particularly Old French prose texts containing substantial amounts of dialogue: prose romances from the early 13th century are known to fit this specification. ${ }^{10}$ Three were selected on the basis that they could readily be searched in electronic versions. ${ }^{11}$ Currently, Old French corpus resources are not tagged for discourse properties, making it a challenge to identify suitable datapoints. Accordingly, lexical items corresponding to the targeted initial constituent types were established as search terms, as follows:

- To represent initial topicalised expressions, a Prepositional Phrase creating a discourse link with the context, using a form of the demonstratives $c e$, cel or cest, for example: apres ce, a ceste fois, de cel don, etc.

- To represent initial focused expressions, an adverb of intensity from among the following lexical set: molt 'much, very', tant 'so much', asez 'very', trop 'very', bien 'really', ${ }^{12}$ as in (23).

(23) a. Moult a granz denz et dedenz et dehors. much have-PRES.3sG large teeth and inside and outside 'It has big teeth both inside and outside.' (La mort le roi Artu, p. 12)

b. Moult fu Lancelos corrouciez por la mort de Gaheriet. much be-PASt.3sg L. anger-PPART for the death of $\mathrm{G}$.

'Lancelot was greatly angered over the death of G.' (La mort le roi Artu, p. 125)

The intensifying meaning conveyed by these expressions allows them to represent the cases of emphatic (though not usually informational) Focus identified in the observational study in 3.1 .

Main clauses with a non-subject in first position and the tensed verb in second position were investigated using the search terms specified above. Clauses with an

\footnotetext{
${ }^{10}$ The constraints imposed by regular versification make verse texts less suitable for syntax research, especially when a good number of prose texts are available, as they are for the period studied here.

${ }^{11}$ These were La Mort le roi Artu, La Queste del saint Graal, searched in the University of Ottawa LFA corpus (Kunstmann 2003) and Merlin, roman en prose I, in an electronic version consulted online. The largest Old French electronic corpus, the Base de Français Médiéval $<$ http://txm.bfm-corpus.org $>$ unfortunately contains only one prose romance, making it inadequate for our purpose.

${ }^{12}$ See Buridant (2000: 742). Note that for Old French bien, the equivalent item bien in Spanish is taken as a left-periphery Focus particle by Hernanz (2010).
} 
impersonal subject were omitted, ${ }^{13}$ as were those introduced by the conjunction $e t$, so as to exclude conjunction as a possible factor influencing the omission of a pronominal subject.

The results of these searches are shown below. The restrictive criteria imposed on the data have limited the sample size somewhat, but the very different tendencies seen in Table 1 are unmistakable. The expression or omission of Spro overwhelmingly reflects the discourse type of initial constituent.

\begin{tabular}{lrrrrr}
\hline \hline & + Spro & \multicolumn{1}{c}{$\%$} & \multicolumn{1}{c}{ Spro } & \multicolumn{1}{c}{$\%$} & Total \\
\hline D-linked PPs: pour/à/après/de/par $+c e$ & 122 & 93.2 & 9 & 6.8 & 131 \\
Intensifiers tant/molt/assez/trop/bien & 3 & 3.0 & 96 & 97.0 & 99 \\
Total & 125 & & 105 & & 230 \\
\hline \hline
\end{tabular}

Table 1: Subject pronoun expression following discourse linked and non-discourse linked constituents, three prose romances from the 13th century

With the intensifiers, taken here as indicating a focus interpretation, Spro was very rarely expressed. They are thus very clearly distinct from clauses with anaphoric initial constituents, such as (24).

(24) De ceste chose est il moult dolans.

of this thing be-PREs.3sg he much grieving

'About this matter, he is very sad.' (Merlin, roman en prose du $13^{e}$ siècle, p. 218)

Here, non-expression of a subject pronoun was almost equally rare. The difference in the expression of subject pronouns in these two contexts was found to be highly significant by Fisher's exact test ( $\mathrm{p}=<0.001,2$-tailed).

It is not being claimed here that the patterns identified by this data sample are exceptionless: discourse linking and focusing are matters where psycholinguistic factors involving the speaker's/writer's stance operate. Especially in a historical context, they may be unrecoverable from the content and context of a solely written documentation. We think, however, that the use in these sample data of items which are strongly identifiable with anaphoricity by demonstrative forms, and focus, by intensifying forms, makes it as clear as can reasonably be expected what the information structure properties of the clause are. The double dissociation between focusing and topicalisation on the one hand, and the expression or omission of the subject pronoun on the other, is not far from complete. The generalisation is thus that null subjects were not normally possible when the initial constituent was discourse-linked. Where the clause-initial constituent was not discourse-linked, however, S was normally left null. Conditions on null S were satisfied, then, as long as no discourse-linked constituent preceded the finite verb. The question that then arises is whether these conditions were structural, or whether the phenomenon can be considered as purely pragmatic.

\footnotetext{
${ }^{13}$ Because the study focused on referential pronouns that could be discourse-linked, impersonal subjects, which could not, were set aside.
} 
Theoretical approaches to the problem of subject pronoun expression/omission in Old French have had to find a way of capturing Foulet's generalisation (that null Spro was grammatical when, if overt, it would have appeared postverbally). This is related to the possibility for an initial non-subject constituent to occupy first position, in which case the subject needed to be postverbal. Government and Binding approaches of the 1980s and 90s proposed that null Spro was licensed only when governed by V in C (Roberts 1993), employing the notion of government, but more recent generative treatments following Minimalist Program assumptions have had to find alternative accounts. Holmberg (2015) and Biberauer et al. (2013) tie the pre-verbal expression of the subject pronoun, as in (1a) to the verb-second property of Old French, such that the left periphery of a finite matrix clause cannot be left empty. We will follow that assumption here, noting, however, that it still leaves the variable postverbal appearance of Spro to be dealt with.

The link between initial focused phrases and null Spro has not to our knowledge been pointed out in the historical syntax literature on Old French, although Vance (1997) did, as we saw, relate postverbal Spro to an anaphoric initial constituent. A new analysis therefore needs to be developed to take account of these findings, and in what follows we propose to ascribe the null Spro phenomenon in Old French to a property of the language remarked upon in the earlier descriptive literature: topic prominence (Rowlett 2007: 8). Note that the term 'topic-prominent' should be seen as a rough characterisation rather than a formal assignment of Old French to a particular category within a crosslinguistically valid typology $(\mathrm{Li}$ and Thompson 1976). The essential characteristic of Old French that is relevant here is its well-known predilection for topic chaining, as in (25).

(25) Et qant Phariens voit ce, si saisit une hache qu' il avoit and when P. see-PREs.3sg this SI seize-PREs.3sg an axe that he haveIMPF.3SG

en la tor maint jor gardee, si s'escorce vers son neveu.

in the tower many day keep-PPART.FEM SI REFL-rush towards his nephew

'And when P. sees this, he seizes an axe which he had kept in the tower for a long time, and rushes towards his nephew.'

(Lancelot du Lac. Tome I, p. 278)

A new topic is often signalled by placing it to the left of $s i$ :

(26) Debonnairetez est de faire granz festes et granz conpaignies... Bounteousness be-PREs.3SG of make-INF great feats and great companies Largesce si est de doner a toz cels en cui li don Generosity SI be-PRES.3SG of give-INF to all those in whom the gifts puent estre bien emploie. be-able-PRES.3SG be-INF well employ-PPART 'Bounteousness is making great feasts and occasions. Generosity is giving to all those in whom the gifts can be well used.'

(Lancelot du Lac. Tome I, p. 220)

In the Middle French period, as the language moved towards its modern subjectprominent character, these traits, as well as null Spro and Verb Second, were lost. 
We therefore propose that Old French null Spro was integrated into the topicprominent character of the left periphery, as the foot member of a topic chain, with the topic operator as its head, as shown in (27).

(27) (Phariens .... saisit une hache) si s'escorce vers son neveu. $\left[{ }_{\text {TopP }} \mathrm{OP}_{\mathrm{i}}\left[\right.\right.$ FinP si s'escorce $\left[\begin{array}{llll}\mathrm{TP} & \mathrm{e}_{\mathrm{i}} & \text { vers son neveu }\end{array}\right]$

Motivation for this analysis is presented in the next section.

\section{AN OPERATOR-VARIABLE ANALYSIS}

Addressing the problem of whether Brazilian Portuguese is a pro-drop language, Modesto (2008) observes that null subjects are licensed only in restricted contexts, specifically in a subordinate clause whose subject is co-referential with that of the main clause.

(28) $\mathrm{O} \quad \mathrm{Feco}_{\mathrm{i}}$ convenceu a Dani que $\mathrm{e}_{\mathrm{i}}$ ganhou o campeonato. the Feco convinced the Dani that won the championship 'Feco convinced Dani that he won the championship.'

Here the understood subject of the subordinate clause can only be coreferential with the matrix subject. Modesto (2008: 380) proposes that a null subject is a variable bound by a higher subject standing in an $\mathrm{A}^{\prime}$ position, the specifier of a functional category FP to which it has moved, and from which it can bind the subordinate clause subject shown as $e$ in (29).

(29) [FP o $\mathrm{Feco}_{\mathrm{i}}\left[\mathrm{TP} \mathrm{t}_{\mathrm{i}}\right.$ convenceu a Dani [CP que $e_{i}$ ganhou o campeonato ]]]

We believe that this analysis may help to clarify null subject properties in Old French, albeit in V2 contexts, rather than in embedded clauses as in Brazilian Portuguese. Following Holmberg and Nikanne (2002) for Finnish, Modesto argues that Brazilian Portuguese is a topic-prominent language, a characterisation which has often been made for Old French (see, e.g., Buridant 2000). ${ }^{14}$ He noted furthermore that in both languages the left periphery preceding the finite verb cannot be left vacant, again a commonality with Old French.

An operator-variable analysis of null subjects is standardly adopted for an undoubted topic-prominent language such as Chinese ( $\mathrm{Li}$ and Thompson 1976). Importantly for present purposes, the variable can be bound not only by an overt subject, as in Brazilian Portuguese, but also by a null topic operator which serves to maintain the topic identity across a sequence of clauses, as can be seen in (30), from $\mathrm{Pu}$ and $\mathrm{Pu}$ (2014: 34).

(30) Duan Quchen wei-ren zhen-pai, ...

D.Q. as-person honorable in work

tong shenmeren dou neng shuo-

shang hua, conglaibu baijiazi.

with anyone all can talk-

a talk never put-on-air

'Duan Quchen was a good leader... he could strike up a conversation with anyone, he never appeared arrogant or remote.'

\footnotetext{
${ }^{14}$ However, these authors ascribe to Topic-prominent languages a constellation of other properties which Old French did not share, so the commonality is only partial.
} 
Chinese subject/topic pronouns are not always omissible, however. In (31), from Pu and $\mathrm{Pu}$ (2014: 40), the omissibility of the subject pronoun $t a$ is seen to depend on whether another constituent is topicalised. In the first clause, (31a), the 3rd-person referent is introduced as the pronoun $t a$, interpretable from preceding context that has been omitted here. In the last two clauses, (31c) and (31d), the same referent is referred to by a null subject. However, in the intervening clause (31b) the object constituent zhe gushi 'this story' is fronted and topicalised, with the result that the subject pronoun $t a$ needs to be overt. Its omission is not acceptable to native speakers consulted.

(31) a. zuijin yiduan shijian ta yizhi zaixie yige gushi, recent period time he keep write a story 'Recently, he has been writing a story.'

b. zhe gushi ta gousile hengjiu this story he think.of very.long 'He has thought about this story for a long time.'

c. izaojiu xiang xie, long.ago want write

'He wanted to write it a long time ago.'

d. ikeshi yizhi meiyou shijian xie. but all.along have.no time write

'But he never had any time to write it.'

In clauses (31c, d), where a subject pronoun is normally unexpressed, there is no such fronted alternative topic to break the topic chain, which allows the subject to be null.

We suggest that the same approach can be adopted for null subjects in Old French, in which a null topic operator in a left-peripheral Topic phrase licenses a post-verbal null subject, with which it is co-indexed to form a topic chain. The Topic head always bears the formal feature [+ anaphoric], thus embodying the traditional view that Old French V2 clauses were 'topic-prominent'. This feature is checked by the null Topic operator. Our analysis is first illustrated with the very common topic-chaining construction using the discourse particle si (MarchelloNizia 1985), as in example (32a) below. Under the analysis offered in (32b), a null topic operator can be taken to have moved from the subject position to [Spec, TopP], and is co-referential with the discourse topic established in the preceding clause, as was seen for Chinese in (30) above.

(32) a. Et ele le regarde, si le conoist. and she him look-at-PREs.3sg SI him know-PREs.3sG

'And she looks at him and recognises him' (La queste del saint Graal, p. 12)

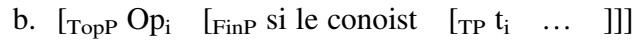

Note that instead of the neutral 'ZP' label used by Labelle and Hirschbühler (2005) to designate the topmost clausal projection, we have taken this projection to be a Topic Phrase, distinct from the position of preverbal focused elements, which we assume 
are positioned in [Spec, FinP]. ${ }^{15}$ So example (17b) above, reproduced below as (33a), has the structure in $(33 b)$.

(33) a. Par mon congié ne movrez hui mes.

b. [Tоре $\mathrm{Op}_{\mathrm{i}} \quad\left[\mathrm{FinP}_{\mathrm{P}}\right.$ Par mon congié ${ }_{\mathrm{Vfin}}$ ne movrez $\left[\mathrm{TTP}_{\mathrm{i}}\right.$ hui mes ]]]

When a deictic/anaphoric constituent is preposed to TopP, however, discourse topic chaining cannot operate, since null-subject operator movement is blocked, as can be seen in example (24) reproduced as (34a), with the structure shown in (34b). With a null subject, the analysis would have been as in (34c).

(34) a. De ceste chose est il moult dolans.

b. [TopP De ceste chose [FinP Vfin est [TP il moult dolans ] ] $]^{16}$

c. [TopP De ceste chose [FinP Vfin est [TP Op moult dolans ]]]

However, in (34c), Op cannot raise to Top, so the structure is ill-formed. Since a null subject required operator movement, the subject pronoun would have had to be overt in this context.

A null-operator-variable analysis thus allows us to explain the key phenomenon under discussion in this study: the difference in subject pronoun realisation between clauses with a preposed Focus element, and those with a Topic element. The structural analysis proposed here accounts for the overwhelming majority of the data discussed in 3.2. The exceptional cases of Spro with preposed focus are presumably benign, in that an overt Spro would also have been available in this context. Exceptional cases of null subjects following a topic are more problematic, however. They may be vestiges of an earlier grammar with different properties that may underlie the freer use of null subjects that seems to be attested in early Old French verse.

\section{SUMMARY}

This article has sought to explore the discoursal and syntactic conditions under which an Old French subject pronoun remained unexpressed. The view taken here is that Zimmermann (2014) represented a substantial advance in linking Focus and null $\mathrm{S}$, but did not offer a theoretically satisfactory explanation of the association, in addition to leaving the status of preposed deictic expressions in the left periphery unclear. Whereas for Zimmermann only focused expressions involved V-movement to the left periphery ( Fin $^{0}$ in the approach taken here), we consider that both preposed Topic and Focus elements produce V2 structures, with V moving to Fin ${ }^{0}$ in both cases.

\footnotetext{
${ }^{15}$ Mathieu (2013: 341) discussed fronted main clause constituents which are not ordinary Topics, but assigns them to a 'Topict' projection. Despite a perhaps infelicitous choice of label, his proposal clearly addressed a distinctive type of preposed element, which may be considered to have the same status as focused constituents in the present analysis. Significantly, the examples he quoted all lacked a postverbal pronominal subject.

${ }^{16}$ For expository convenience we ignore cliticisation of $i l$ to Vfin.
} 
The central claim made here is then that the presence of a fronted anaphoric/deictic topic regularly requires a pronominal subject to be expressed, whereas a fronted Focus element regularly leaves it null.

We have examined data drawn from narrative prose which point to the conclusion that subject pronoun (non-) expression was very strongly related to the discoursal nature of material in the left periphery, at least in root causes - subordinate clauses require separate treatment. When fronted, discourse-linked elements rarely permitted null subjects, and non-discourse-linked elements even more rarely permitted overt pronominal subjects. On a wider and more systematic basis, then, this study has confirmed the proposal of Vance (1997) that after a deictic constituent in the left periphery, a subject pronoun tended to be obligatory. Her contention that subject pronouns were otherwise optional has had to be qualified, however, insofar as fronted elements appearing to have an emphatic focus function overwhelmingly avoided co-occurrence with an overt pronominal subject.

The structural account of this empirical contrast that we have proposed relies on the analysis, by Modesto (2008) and others, of partial null subject languages, to the effect that in such languages null subjects are co-indexed with a c-commanding Topic constituent. Languages of this type are considered 'topic-prominent', a label which seems to suit Old French rather well. On that basis, we have applied to Old French the notion of a topic chain involving a null topic operator, an analysis standardly used for topic-prominent languages such as Chinese. A strength of this analysis is that it accounts straightforwardly for the very common null subject clauses with particle $s i$ found in running narrative where the same entity is interpreted as the subject of successive root clauses in the discourse. It is then shown that if the syntactic Topic position is filled by a D-linked nonsubject constituent, a null subject cannot be licensed, as the null operator is blocked from raising to Spec TopP.

The analysis proposed requires preverbal focused elements to front to a different position from that occupied by Topic constituents. Insofar as this attributes to Old French a split left periphery, the availability of two preverbal projections might therefore appear to conflict with the strongly verb-second character of the language. However, V3 sequences that would have been produced by the surface order TopFoc-VFin were independently ruled out by the bottleneck condition (Holmberg 2015) on FinP, by which the constituent moved there to check FinP's EPP feature prevented another constituent from moving through it on its way to Top or Focus. Hence V3 constructions in Old French were normally possible only if the first element was in extraposition, as discussed by Skårup (1975).

The discourse contrast in contexts with pronominal versus null subjects has thus been shown to receive a plausible structural explanation grounded in a current analytic framework that fits the generally accepted character of Old French. However, given the confines of the present article, the empirical findings that motivate the proposed analysis must be regarded as provisional, and further exploration of the information structure properties of the Old French left periphery are clearly called for. The extreme contrast between D-linked fronted constituents and fronted intensifiers in whether they can occur with null subjects leaves little room for doubt that there was a systematic constraint on novel subject to availability. Nevertheless, research 
into a wider variety of clause-initial constituent types is needed, so as to test the applicability of the analysis proposed here. To do so, corpus resources with the discoursal tagging would clearly be advantageous, though the logistical and analytic challenges involved in creating them should not be underestimated. We hope to have shown in the present study that this would be a worthwhile enterprise, likely to benefit both scholars interested in the discourse pragmatics of historical language varieties, and those concerned more with their syntactic properties. The importance of discourse factors in explicating the syntactic properties of Old French would seem to make highly desirable such a convergence of research interests on the need for corpus resources facilitating both approaches.

\section{LITERARY WORKS CITED}

de Joinville, Jean. Histoire de Saint Louis. Ed. Natalis de Wailly, 1868. Paris: Renouard. [1309]

Lancelot du Lac. Tome I. Ed. François Mosès, 1991. Le Livre de Poche, coll. "Lettres gothiques".

Lancelot du Lac. Tome II. Ed. François Mosès, 1993. Le Livre de Poche, coll. "Lettres gothiques".

Lancelot du lac : La Fausse Guenièvre. Tome III. Ed. François Mosès, 1998. Le Livre de Poche, coll. "Lettres gothiques".

Merlin, roman en prose du $13^{e}$ siècle. Ed. Gaston Paris et Jacob Ulrich, 1886. Paris: FirminDidot. Online version at $<$ https://archive.org/stream/merlinromanenpro01 robeuoft $/$ merlin romanenpro01robeuoft_djvu.txt>

La Mort le roi Artu. Ed. Jean Frappier, 1964. Genève: Droz.

La Queste del saint Graal. Ed. Albert Pauphilet, 1949. Paris: Champion.

Roman de Tristan en prose. Ed J. Blanchard, 1976. Paris: Klinksieck.

\section{REFERENCES}

Biberauer, Theresa, Anders Holmberg, Ian Roberts, and Michelle Sheehan. 2013. Complexity in comparative syntax: The view from modern parametric theory. In Measuring linguistic complexity, 3ed., ed. Fritz Newmeyer and Laurel Preston, 103-127. Oxford: Oxford University Press.

Buridant, Claude. 2000. Nouvelle grammaire de l'ancien français. Paris: Sedes.

Donaldson, Bryan. 2012. Initial subordinate clauses in Old French: Syntactic variation and the clausal left periphery. Lingua, 122(9): 1021-1046.

Elsig, Martin, and Esther Rinke. 2007. Les adverbes et l'inversion en ancien français. Le Nouveau Corpus d'Amsterdam soumis à l'analyse linguistique. In Le Nouveau Corpus d'Amsterdam: Actes de l'atelier de Lauterbad, ed. Pierre Kunstmann, and Achim Stein. Stuttgart: Steiner.

Foulet, Lucien. 1928. Petite syntaxe de l'ancien français. Paris: Champion.

Foulet, Lucien. 1935/6. L'extension de la forme oblique du pronom personnel en ancien français. Romania 61(243): 257-315; 401-463; Romania 62(245): 27-91. 
Frascarelli, Mara. 2007. Subjects, topics and the interpretation of referential pro: An interface approach to the linking of (null) pronouns. Natural Language and Linguistic Theory 25 (4): 691-734.

Grimshaw, Jane, and Vieri Samek-Lodovici. 1998. Optimal subjects and subject universals. In Is the best good enough? Optimality and competition in syntax, Ed. Pilar Barbosa, Danny Fox, Paul Hagstrom, Martha McGinnis, and David Pesetsky, 193-219. Cambridge, MA: MIT Press.

Hernanz, Maria Lluïsa. 2010. Assertive bien in Spanish and the left periphery. In Mapping the left periphery, ed. Paola Benincà and Nicola Munaro, 19-62. Oxford: Oxford University Press.

Holmberg, Anders. 2010. Parameters in minimalist theory: The case of Scandinavian. Theoretical Linguistics 36(1): 1-48.

Holmberg, Anders. 2015. Verb second. In Syntax: Theory and analysis. An international handbook, ed. Tibor Kiss and Artemis Alexiadou, 242-283. Berlin: Mouton de Gruyter.

Holmberg, Anders, and Urpo Nikanne. 2002. Expletives, subjects, and topics in Finnish. In Subjects, expletives, and the EPP, ed. Peter Svenonius, 71-106. Oxford: Oxford University Press.

Ingham, Richard. 2005. Adverbs and the syntax of subjects in Old French. Romania 123(489): 99-122.

Ingham, Richard. 2016. Investigating language change using Anglo-Norman spoken and written register data. Linguistics 54(2): 381-409.

Kaiser, Georg. 2002. Verbstellung und Verbstellungswandel in den romanischen Sprachen [Verb position and verb position change in the Romance languages]. Tübingen: Niemeyer.

Kunstmann, Pierre. 2003. Textes de Français Ancien (TFA), $2^{\text {nd }}$ version. Université d'Ottawa. $<$ http://artfl-project.uchicago.edu/content/tfa $>$

Labelle, Marie, and Paul Hirschbühler. (this issue). Topic and Focus in Old French V1 and V2 structures.

Labelle, Marie, and Paul Hirschbühler. 2005. Changes in the clausal organization and the position of clitics in Old French. In Grammaticalization and parametric variation, ed. Montserrat Batllori, Maria Lluïsa Hernanz, Carme Picallo, and Francesc Roca, 60-71. Oxford: Oxford University Press.

Lambrecht, Knud. 1994. Information structure and sentence form: Topic, focus, and the mental representation of discourse referents. Cambridge: Cambridge University Press.

Li, Charles N., and Sandra Thompson. 1976. Subject and topic: A new typology of language. In Subject and topic, ed. Charles N. Li, 457-491. New York: Academic Press.

Marchello-Nizia, Christiane. 1985. Dire le vrai: L'adverbe "si" en français médiéval. Geneva: Droz.

Mathieu, Éric. 2013. The left periphery in Old French. In Research in Old French: The state of the art, ed. Deborah Arteaga, 327-350. Dordrecht: Kluwer.

Modesto, Marcelo. 2008. Topic prominence and null subjects. In The limits of syntactic variation, ed. Theresa Biberauer, 375-410. Amsterdam: John Benjamins.

Prévost Sophie. 2011. Expression et position du sujet pronominal en français. In Mémoires de la Société de Linguistique de Paris, Tome XIX: L'Evolution grammaticale à travers les langues romanes', ed. Jacques François, and Sophie Prévost, 13-33. Available at: $<$ https://hal.archives-ouvertes.fr/halshs-00665183/document $>$.

Price, Granville. 1973. Sur le pronom personnel sujet postposé en ancien français. Revue Romane 8: 226-236.

$\mathrm{Pu}$, Ming-Ming, and Qinghong Pu. 2014. Zero anaphora and topic chain: A cross-linguistic study. International Journal of Linguistics and Communication 2(1): 27-44. 
Rinke, Esther. 2003. On the licensing of null subjects in Old French. In Syntactic structures and morphological information, ed. Uwe Junghanns, and Luka Szucsich, 101-127. Berlin: Mouton De Gruyter.

Roberts, Ian. 1993. Verbs and diachronic syntax. Dordrecht: Kluwer.

Rowlett, Paul. 2007. The syntax of French. Cambridge: Cambridge University Press.

Schegloff, Emanuel, and Harvey Sacks. 1973. Opening up closings. Semiotica 8(4): 289-327.

Skårup, Povl. 1975. Les premières zones de la proposition en ancien français. Essai de syntaxe de position. Études Romanes de l'Université de Copenhague. København: Akademisk Forlag.

Vance, Barbara. 1997. Syntactic change in Medieval French: Verb-second and null subjects. Dordrecht: Kluwer.

Zimmermann, Michel. 2014. Expletive and referential subject pronouns in Medieval French. Berlin: de Gruyter.

Zubizarreta, Maria Luisa. 1998. Prosody, Focus, and Word Order. Cambridge, MA: MIT Press. 